\title{
Ryegrass straw and wood shavings as bulking agents on swine slurry co-composting: a case study in Southern Brazil
}

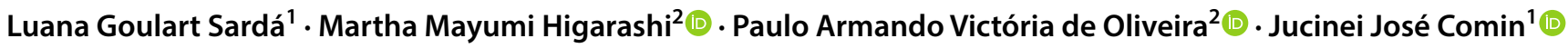

Received: 3 October 2018 / Accepted: 17 April 2019 / Published online: 27 April 2019

(c) The Author(s) 2019

\begin{abstract}
Purpose Adoption of co-composting to treat swine slurry can reduce risks of pollution and produce organic fertilizer. Wood shavings and sawdust are the usual bulking agents used in such treatments, however planted forest is a feedstock source of slow renewability rate. Thus, the prospection of alternative biomass feedstock in regions of high animal density, may enable the pig slurry co-composting. Therefore, this manuscript describes a case study carried in Southern Brazil, region that houses $56 \%$ of Country's swine herd, and where ryegrass is a common winter cover crop.

Methods A study was conducted to evaluate the effect of increasing shares of ryegrass straw in the bulking agent of swine slurry co-composting, as follow: wood shaving $(W)$, ryegrass straw $(S)$ and blends ( $W / S=50 / 50$ and $30 / 70$ ). Composting evolution was monitored during 85 days by measuring daily the temperature and emissions of $\mathrm{CO}_{2}, \mathrm{CH}_{4}$ and $\mathrm{NH}_{3}$, afterwards at 100th day the resulting composts were characterized.

Results The increase in straw shares, elevated temperature peaks $\left(>60^{\circ} \mathrm{C}\right)$, accelerated the biomass stabilization from $>85$ to 65 days, and produced fertilizers with higher nutrient content due to its higher biodegradability, though $\mathrm{NH}_{3}-\mathrm{N}$ emission increased up to $10 \%$. The maintenance of a share of wood shavings can mitigate that emission, besides improve the stability of pile temperature and decrease leaching.

Conclusions Although ryegrass straw can total or partially substitute wood shavings in swine slurry co-composting, substrates blends were more promising. Further studies approaching management adjusts are required to prevent increasing the emission of $\mathrm{NH}_{3}-\mathrm{N}$ and leaching.
\end{abstract}

Keywords Livestock $\cdot$ Environmental impact $\cdot$ Wastewater treatment $\cdot$ Compost $\cdot$ Substrates

\section{Introduction}

The intensification of livestock industry in Concentrated Animal Feed Operations (CAFOs) is a global trend driven by increased profits achieved through the economies of scale (Sorathiya et al. 2014). Contrasting to this tendency, the European Union has recently adopted some policies that intend to inhibit the uncontrolled growth of this model aimed to achieve certain environmental goals aimed to sustain the balance between urban and rural populations and strengthen the family-based small farms. Such measures have had an

Martha Mayumi Higarashi

martha.higarashi@embrapa.br

1 Federal University of Santa Catarina, Rod. Admar Gonzaga, 1346, Florianópolis, SC 88034-000, Brazil

2 Embrapa Suínos e Aves, BR-153, Km110, Vila Tamandua, Concórdia, SC 89715-899, Brazil indirect effect on accelerating the expansion of CAFOs in developing countries to supply the world's growing demand for meat (Macleod et al. 2013).

In Brazil, the expressive growth of livestock production consolidates the Country as one of the largest meat exporter (FAO 2015). In recent years, however, have emerged some questions about the sustainability of this production chain in keeping the current growth rates. Furthermore, the pressure under livestock industry is increasing as long as the evidence of natural resources impairment arise in regions of intense animal production, especially in Southern Brazil, the region that houses $56 \%$ of Country's swine herd.

These contaminations are usually associated to the excess of nitrogen and phosphorus originated from animal manure which cumulates in soil and eventually washed into water bodies by lixiviation and can cause their eutrophication (Lee and Oa 2013; Cherubini et al. 2015). Furthermore, in recent years, emissions of greenhouse 
gases (GHG) and $\mathrm{NH}_{3}$ have also become a major focus of environmental concern related to pig farms (Macleod et al. 2013; Philippe and Nicks 2015; Dennehy et al. 2017).

It is important to highlight that Brazil had voluntarily committed to reduce the emission of GHG by $36-39 \%$ by 2020 at Copenhagen COP15 (Cardoso et al. 2016).

Nowadays Brazilian Ministry of Agriculture, Livestock and Food Supply (MAPA 2009) certificates organic fertilizer resulting from composting process demonstrably controlled and well-conducted which enable them to be sold, exporting their nutrients and support organic farming, moreover composting is considered a global warming mitigation technology, therefore, it is eligible for funding by a Brazilian government program called ABC program, whose letters $\mathrm{ABC}$ are the initial of Agriculture of Low Carbon in Portuguese (Angelo 2012).

Composting is an ancient technology known since Biblical era, and consists in stabilize and reduce volume and mass of solid organic wastes through biological processes to produce a rich, safe and stable soil conditioner (Wang et al. 2016). Its main advantage is to enable the nutrients and organic matter cycling in agricultural systems (Adhikari et al. 2009).

Nevertheless, taking in account the ideal moisture content for composting as being approximately $60 \%$, it is clearly noticed that swine slurries have excess of water and tend to be degraded by anaerobic routes. Therefore, to induct and ensure the proper evolution of composting process and the prevalence of aerobic biodegradation, interventions such as the addition of bulking agents with low water content and rich in carbon, as well as oxygen incorporation by biomass turning are required (Cook et al. 2015; Qasim et al. 2018).

The raw materials most widely used as bulking agent for composting are wood shavings and sawdust, however, they can be costly in regions with intensive animal production once they are highly demanded for piglets and broilers heating and beds. In countries where raw materials from forest are scarce, many studies had been conducted assessing alternative bulking agents such as straws, crops residues, chopped newspaper, paperboard, etc. (Adhikari et al. 2009; De Guardia et al. 2010a; Ren et al. 2010).

Measures to diversify the supply sources of raw materials for bulking agents is strategical for co-composting succeed in Brazil, to provide flexibility and allow the adaptation of the process to diverse bioclimatic and cultural conditions existing in a continental dimension country. Taking this into account; ryegrass (Lolium multiflorum) is an annual grass widely spread in Southern Brazil, commonly grown as winter pasture (Ribeiro et al. 2009). Due to its high renewability (compared to cultivated forests) and availability in the region which concentrates $56 \%$ of the Brazilian pig herd, a case study was conducted to evaluate ryegrass straw as a substitute to wood shavings as the bulking agent of swine slurry co-composting.

Therefore, the aim of this work was to assess ryegrass straw as a total or partial substitute to wood shavings as bulking agent on swine slurry co-composting, also to evaluate its advantages and disadvantages considering environmental impact and check whether the resulting compost achieves the quality standard demanded by the current Brazilian Law (MAPA 2009).

\section{Materials and methods}

\section{Experimental setup}

A pilot scale assay was carried out inside a transparent PVC film greenhouse located in Santa Catarina State, Brazil $\left(27^{\circ} 18^{\prime} 34^{\prime \prime} \mathrm{S} ; 51^{\circ} 59^{\prime} 30^{\prime \prime} \mathrm{W}\right)$. The experiment was conducted throughout 85 days during summer season (from November to January) and the experimental set-up consisted in four concrete cells of $3 \mathrm{~m}^{3}[2.5(l) \times 1.5(w) \times 0.8(h) \mathrm{m}]$ where the composting piles were assembled.

A composting pile were built in each cell using the rate slurry/bulking agent of 6/1 (in weight), differing from each other just in the composition of bulking agents given in percentage (weight): wood shavings $100 \%(W)$; wood shavings $50 \%$ + ryegrass straw $50 \%$ in weight $(W / S-50 / 50)$; wood shavings $30 \%$ + ryegrass straw $70 \%(W / S-30 / 70)$ and ryegrass straw $100 \%(S)$.

Initially the piles were assembled by placing a $50 \mathrm{~cm}$ high layer of bulking agents in the cells, then swine slurry was uniformly distributed over the substrate surface using a watering can. The process was repeated three times but with bulking agents layers of $10 \mathrm{~cm}$ high instead of $50 \mathrm{~cm}$, to obtain piles of $80 \mathrm{~cm}$ of total hight, completely filling the $3 \mathrm{~m}^{3}$ cells.

Due to the distinct density of wood shavings $\left(183 \mathrm{~kg} \mathrm{~m}^{-3}\right)$ and ryegrass straw $\left(120 \mathrm{~kg} \mathrm{~m}^{-3}\right)$ the mass of bulking agents contained in the piles differs, being: $(W)=549 \mathrm{~kg},(W / S-$ $50 / 50)=454 \mathrm{~kg},(W / S-30 / 70)=416 \mathrm{~kg}$ and $(S)=359 \mathrm{~kg}$.

The fresh swine slurry was obtained from a demo finishing facility, located in the same experimental area, which houses 48-swines with an average manure production of $0.34 \mathrm{~m}^{3}$ day $^{-1}$. The slurry was incorporated to substrates in installments along 49 days according to the schedule shown in Table 1, to obtain a final ratio of $6 \mathrm{~L}$ of swine slurry per $1 \mathrm{~kg}$ of bulking agent.

Samples of slurry at each addition were collected and analyzed according to standard methods (APHA et al. 1999) for the parameters: organic carbon (OC), total kjeldahl nitrogen (TKN) and the solid series-total solids (TS), fixed (FS) and volatiles (VS). The average characteristics of slurries at each are shown in Table 2. 
Table 1 Chronogram of slurry application and biomass turning

\begin{tabular}{lllllll}
\hline $\begin{array}{l}\text { Number of } \\
\text { application }\end{array}$ & Day & \multicolumn{3}{c}{ Volume of added slurry $(\mathrm{L})$} & \multirow{2}{*}{$\begin{array}{l}\text { Weekly share of the } \\
\text { total slurry added (\%) }\end{array}$} \\
\cline { 2 - 6 } & & $(W)$ & $(W / S-50 / 50)$ & $(W / S-30 / 70)$ & $(S)$ & \\
\hline 1 & 1 & 439.2 & 363.0 & 332.5 & 286.8 & 40 \\
2 & 3 & 439.2 & 363.0 & 332.5 & 286.8 & \\
3 & 7 & 439.2 & 363.0 & 332.5 & 286.8 & \\
4 & 14 & 329.4 & 272.3 & 249.4 & 215.1 & 30 \\
5 & 17 & 329.4 & 272.3 & 249.4 & 215.1 & \\
6 & 21 & 329.4 & 272.3 & 249.4 & 215.1 & \\
7 & 28 & 219.6 & 181.5 & 166.3 & 143.4 & 20 \\
8 & 31 & 219.6 & 181.4 & 166.3 & 143.4 & \\
9 & 35 & 219.6 & 181.4 & 166.3 & 143.4 & \\
10 & 49 & 329.4 & 272.3 & 249.4 & 215.1 & 10 \\
Total & & 3294 & 2722.5 & 2494 & 2151 & 100 \\
\hline
\end{tabular}

Table 2 Physical-chemical characteristics of swine slurries used at each application

\begin{tabular}{lllllc}
\hline $\begin{array}{l}\text { Applica- } \\
\text { tions }\end{array}$ & OC $(\%)$ & TKN $(\%)$ & TS $\left(\mathrm{g} \mathrm{L}^{-1}\right)$ & $\mathrm{VS}\left(\mathrm{g} \mathrm{L}^{-1}\right)$ & $\mathrm{FS}\left(\mathrm{g} \mathrm{L}^{-1}\right)$ \\
\hline 1 & 2.9 & 0.312 & 60.0 & 48.7 & 11.3 \\
2 & 2.2 & 0.371 & 41.8 & 31.8 & 9.94 \\
3 & 1.9 & 0.411 & 33.7 & 25.2 & 8.50 \\
4 & 1.5 & 0.294 & 33.7 & 24.4 & 9.23 \\
5 & 2.7 & 0.467 & 39.7 & 29.0 & 10.7 \\
6 & 2.1 & 0.344 & 32.6 & 24.4 & 8.20 \\
7 & 2.6 & 0.306 & 48.0 & 35.3 & 12.7 \\
8 & 2.4 & 0.431 & 51.9 & 37.9 & 14.0 \\
9 & 2.8 & 0.305 & 45.9 & 33.2 & 12.7 \\
10 & 2.7 & 0.296 & 38.7 & 26.9 & 11.8 \\
\hline
\end{tabular}

The volume of slurry added to substrates were deliberately higher than their capacity of sorption to find out the maximum volume that each bulking agent are capable of treating and also to obtain richer final fertilizers. The leachates from the composting piles were individually collected from the drains and their volume were measured before being reintroduced to their respective treatment piles. This procedure was repeated until leaching had completely ceased.

Throughout the impregnation period (49 days) the biomass was turned at every slurry load, thereafter the turning frequency was reduced to twice a week. Once the impregnation step had finished, biomass samples from each treatment were collected and immediately sent to laboratory to analyze organic carbon (OC), total nitrogen (TN) and dry matter (DM) according to standard methods (AOAC 1998).

\section{Composting process monitoring}

The composting progress was daily monitored by measuring biomass temperature and emission of carbon dioxide $\left(\mathrm{CO}_{2}\right)$ which are indirect indicators of aerobic activities (Paillat et al. 2005; Malinska et al. 2014).

The internal temperature of composting piles were measured with $\mathrm{Cu}-\mathrm{Constantan}$ termopars inserted at $20-30 \mathrm{~cm}$ depth and $\mathrm{CO}_{2}$ emission was measured according to previous published work (Sardá et al. 2010) which used the static chamber method to collect the gas (Rawluk et al. 2001; Sommer et al. 2004; Smith et al. 2007) coupled to infrared portable detector (X-AM 7000, Dräger-Lübeck, Germany). Gas samples were collected in three points per pile during 3 min and fluxes were calculated using Eq. (1) (Sommer and Møller 2000):

$F=\frac{V}{A} \cdot \frac{\Delta C}{\Delta t}$,

where $V$ is the volume of the static chamber $\left(\mathrm{m}^{3}\right) ; A$ is the emitting surface area $\left(\mathrm{m}^{2}\right) ; \frac{\Delta C}{\Delta t}=$ rate of $\left[\mathrm{CO}_{2}\right]$ increase in the headspace of the static chamber $\left(\mathrm{g} \mathrm{m}^{-3} \mathrm{~min}^{-1}\right)$.

The emission of ammonia $\left(\mathrm{NH}_{3}\right)$ was evaluated because this parameter has a direct correlation with the nutritional quality of the final compost, beside it also has influence on the technologies' environmental and social impacts once it is a gas that is pollutant, odorous and toxic.

Ammonia was measured using a portable gas detector with ammonia electrochemical sensor (X-AM 7000, DrägerLübeck, Germany). The sampling method was modified once static chambers usually sub estimates $\mathrm{NH}_{3}$ emission (Smith et al. 2007) because the confined environment of the chamber favor the reduction on $\mathrm{NH}_{3}$ diffusion rate and also the condensation of water vapor which solubilizes gaseous $\mathrm{NH}_{3}$ and removes it from the headspace.

Therefore, sampling was made according to Smith et al. (2007) using a wind tunnel which covered $1 \mathrm{~m}^{2}$ of emitting 
Table 3 Initial characteristics of biomass from the treatments evaluated

\begin{tabular}{lclll}
\hline Treatment & OC $(\%)$ & TN $(\%)$ & C/N & DM (\%) \\
\hline$W$ & 10.93 & 0.40 & 27.33 & 29.09 \\
$W / S-50 / 50$ & 9.94 & 0.48 & 20.70 & 26.55 \\
$W / S-30 / 70$ & 7.83 & 0.55 & 14.23 & 25.96 \\
$S$ & 4.44 & 0.66 & 6.73 & 21.31 \\
\hline
\end{tabular}

surface and gas exhausting at laminar flow fixed at $0.015 \mathrm{~m}^{3}$ $\mathrm{s}^{-1}$ (Lockyer and Whitehead 1990; Rochette et al. 2001). Emissions were measured during $10 \mathrm{~min}$ per pile and the emission flow $(F)$ was calculated using Eq. 2:

$F=\frac{f}{A_{\mathrm{s}}}\left(c_{\mathrm{o}}-c_{\mathrm{i}}\right)$,

where $f$ is the laminar flow in tunnel $\left(\mathrm{m}^{3} \mathrm{~s}^{-1}\right) ; A_{\mathrm{S}}$ is the emitting surface area covered by the tunnel $\left(\mathrm{m}^{2}\right) ; C_{\mathrm{i}}$ and $C_{\mathrm{o}}$ is the concentrations of $\mathrm{NH}_{3}-\mathrm{N}$ inlet and outlet of the tunnel, respectively $\left(\mathrm{g} \mathrm{NH}_{3}-\mathrm{N} \mathrm{m}^{-3}\right)$.

Accumulated $\mathrm{NH}_{3}-\mathrm{N}$ losses are calculated by the integration of the graphic $F$ vs. time.

To evaluate the quality of resulting composts and check if they are in compliance with the applicable law and regulations (MAPA 2009), samples were collected from each pile at 100th day and analyzed for potassium $(\mathrm{K})$, total nitrogen $(\mathrm{TN})$, phosphorus $(\mathrm{P})$, organic carbon $(\mathrm{OC})$ and $\mathrm{pH}$ (AOAC 1998).

\section{Results and discussion}

The sorption capacity of all tested bulking agents were exceeded, resulting in leachates that were individually collected from each composting pile. The percentages of leaching relative to the total volume added were: $7.5 \%(\mathrm{~W}), 10 \%$ (W/S-50/50), 15\% (W/S-30/70) and 29\% (S). Therefore, the treatment capacity can be improved by increasing the proportion of wood shavings.

Table 3 shows the characteristics of the biomasses of the four piles resulting from the incorporation of swine slurry to bulking agents as described in Table 1 .

The moisture content varied from 71 to $79 \%$ for $(W)$ and $(S)$, respectively. These values are above the recommended $60 \%$ which was expected once slurry was deliberately added in excess. The $\mathrm{N}$ content increases proportionally to straw content on bulking agent, this may occur because ryegrass itself can contribute to the enrichment of biomass with nitrogen (Horwath and Elliott 1996) therefore, all the biomass, except for $(W)$, had $\mathrm{C} / \mathrm{N}$ ratio below the range that are considered ideal for composting $(25 \leq \mathrm{C} / \mathrm{N} \leq 35)$. This imbalance caused by the excess of $\mathrm{N}$ is undesirable because it can increase $\mathrm{NH}_{3}$ emission during composting.

The graphics resulting from temperature and gases emissions measurements are shown in Fig. 1. Results have shown that the temperature of piles with higher wood shavings content (Fig. 1a, b) presented lower maximum peaks and less fluctuations. This may occur because wood shavings has higher density and insulation capacity which combined to its lower porosity turns the biomass less susceptible to external temperature variations, besides the wood shavings provides physical conditions that limits gaseous exchanges between biomass and atmosphere.

According to El Kader et al. (2007) this behavior occurs because raw materials with lower density and high porosity has inner spaces filled with free air which favor gaseous exchanges, as well as vapor and heat losses resulting in the rapid rise of biomass temperature in the beginning of composting.

Additionally, as wood shavings has lower biodegradability due to its high content of recalcitrant molecules such as lignin and cellulose, the kinetic of decomposition of organic matter of this substrate is slower with low microbiological activity and consequently the maximum temperature developed during composting of this biomass may be lower.

According to De Guardia et al. (2010b), the self-heating capacity of biomass is strongly related to its biodegradability, however, it is impossible to predict this heating relied only on raw materials biodegradability, because the physical characteristics of the materials also play a key role on the kinetics of residues stabilization because it has direct influence on the retention capacity of heat and moisture as well as on the aeration of this piles.

Results from the present work showed that the presence of wood shavings seems to retard the stabilization of composts because any $\mathrm{CO}_{2}$ emission was observed in the pile containing only straw after 65 days of measurements (Fig. 1d), besides, the internal temperature of the pile also dropped from this day on, which may indicate the stabilization of biomass. Meanwhile during the whole experimental period ( 85 days) the aerobic biodegradation of organic matter proceed in all piles that contained wood shavings on bulking agent composition, as can be seen in Fig. 1a-c.

Similar results were reported by Sommer and Møller (2000), the authors concluded that the bulking agents with higher density and less porous extends the treatment time.

Temperature plays an important role on compost sanitation and ensure its safety use without harming human health (Malinska et al. 2014). Although in Brazil there is no specific law that requires a minimum temperature to be reached during commercial composting operations, it is possible to make an exercise using temperature requirements compiled from some selected countries laws as reference (Table 4) to estimate the sanitation level of the resulting composts. 

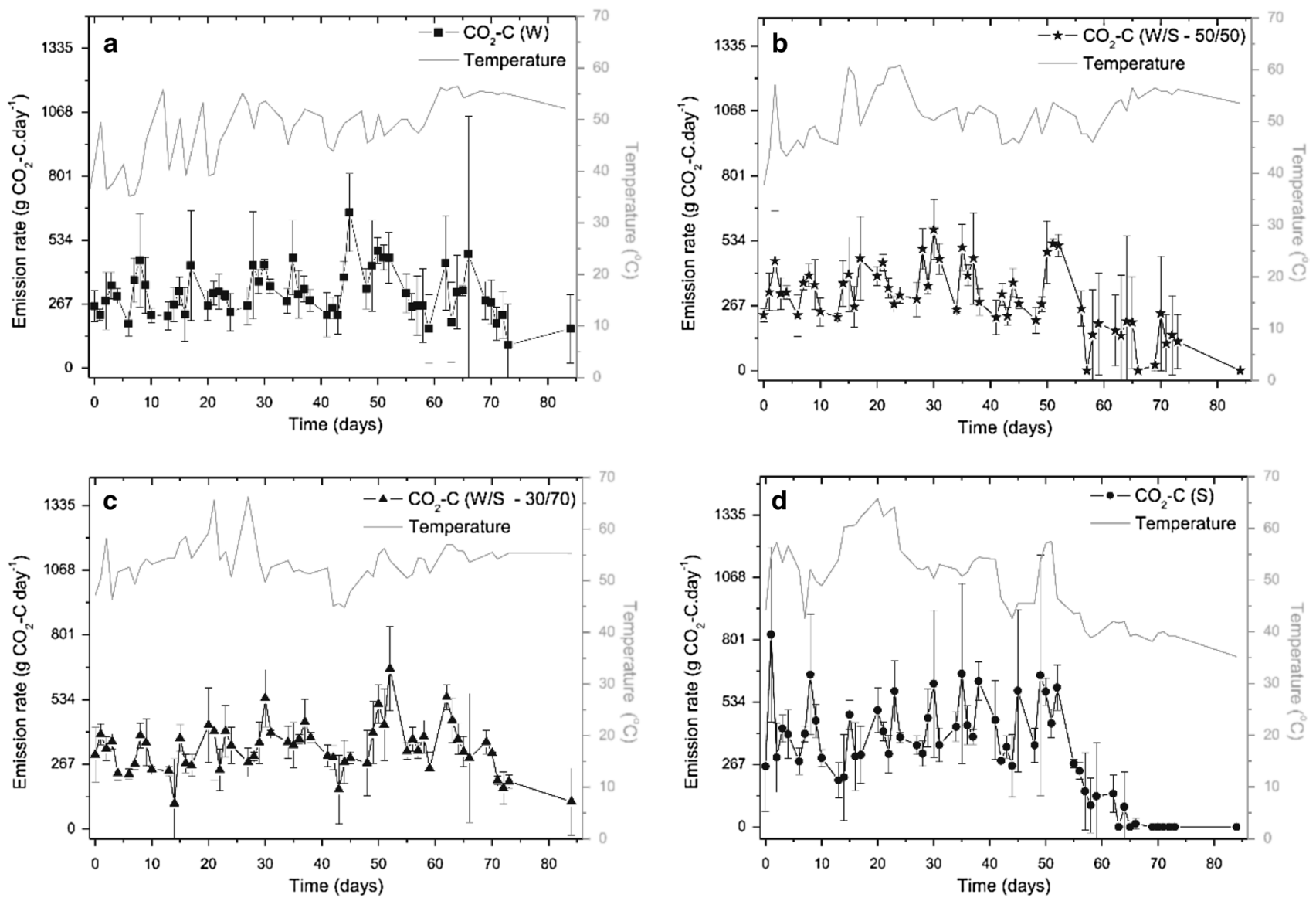

Fig. 1 Emission rate of $\mathrm{CO}_{2}-\mathrm{C}$ and $\mathrm{CH}_{4}-\mathrm{C}\left(\mathrm{g} \mathrm{C}\right.$ day ${ }^{-1}$ per pile) and internal pile temperature: a wood shavings $(\mathrm{W})$; b wood shavings $50 \%$ and straw 50\% (W/S-50/50); c wood shavings $30 \%$ straw $70 \%(\mathrm{~W} / \mathrm{S}-30 / 70)$ and $\mathbf{d}$ straw $(S)$

Table 4 Minimum temperature and time requirement for compost sanitation according to laws from selected countries Adapted from Reinhard (2006)

\begin{tabular}{lll}
\hline Country & Temperature $\left({ }^{\circ} \mathrm{C}\right)$ & Time (days) \\
\hline Denmark & 55 & 14 \\
French and Belgium & 60 & 4 \\
The Netherlands & 55 & 4 \\
Italy and USA & 55 & 3 \\
Germany & $55 / 65$ & $14 / 7$ \\
\hline
\end{tabular}

According to Fig. 1, the composting piles containing wood shavings ( $\mathrm{a}, \mathrm{b}$ and $\mathrm{c}$ ) reached temperature higher than $55^{\circ} \mathrm{C}$ for more than 14 consecutive days from the 60th day until the end of the experiment. The resulting composts, therefore, are in compliance to most of the laws listed on Table 4, except for French and Belgium.

Temperatures above $60{ }^{\circ} \mathrm{C}$ were achieved by bins that contained straw (b, c and d) but just for a short period of time (3-4 days) in the intervals between slurry additions in the beginning of the treatments. In the bin that contained only straw (d) the temperatures above $60{ }^{\circ} \mathrm{C}$ lasted longer (approximately 10 days) during the period of slurry applications (between the 15th and 25th days), however, it is important to highlight that after the last application of slurry the temperature remained above $55^{\circ} \mathrm{C}$ only for 3 days and quickly dropped soon after this, until it reaches equilibrium with room temperature.

Once the swine slurry is the main risk agent for an eventual biological contamination of the compost, it is important that all the amount of slurry added to the biomass was submitted to the whole thermic treatment. Therefore, considering only the time and temperature developed after the last slurry addition, it is possible to conclude that although straw pile $(d)$ developed the highest temperature, a significant parcel of the slurry was added in periods that were posterior of the temperature peaks, than it was concluded that this treatment would attend only Italy and USA laws.

The accumulated losses of $\mathrm{NH}_{3}-\mathrm{N}$ for the four treatments throughout 85 days are shown in Fig. 2.

These results show that in the first 20 days of experiment the emissions are relatively low, this period may correspond to the time required for the ammonification of 


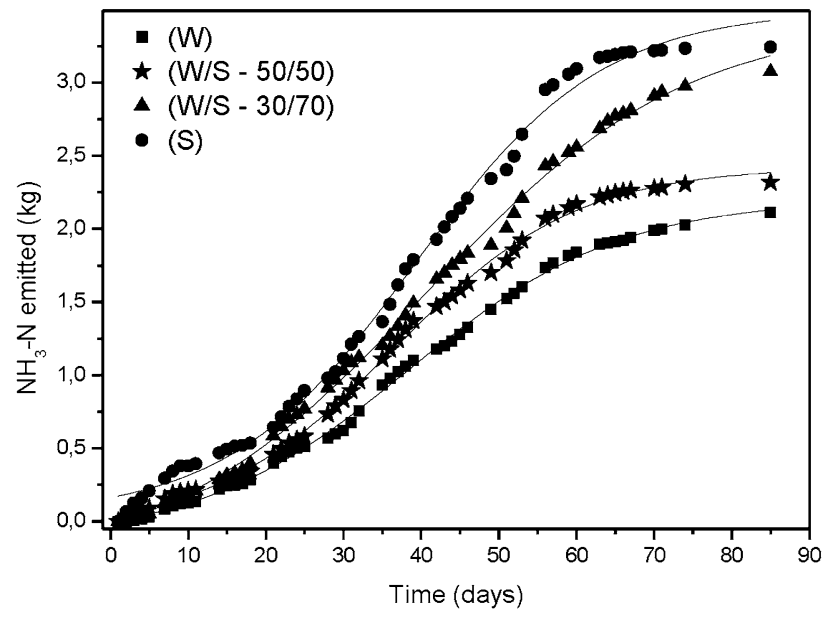

Fig. 2 Accumulated emission of $\mathrm{NH}_{3}-\mathrm{N}$ from composting piles in 85 days

organic nitrogen. According to de Guardia et al. (2008) the highest peaks of $\mathrm{NH}_{3}$ emissions normally are simultaneous with temperature and oxygen consume peaks which indicates that the ammonification of organic nitrogen occurs by biodegradation then it is relatively proportional to organic carbon mineralization rates. Therefore, this process is more intense in the beginning of composting and in the presence of labile organic matter (Paillat et al. 2005; Matsumura et al. 2010).

The $\mathrm{NH}_{3}-\mathrm{N}$ resulting from ammonification can volatilize, be converted into nitrate by nitrification or be immobilized in the microbial biomass. Results showed that the highest $\mathrm{NH}_{3}$ emission rates were observed between 20th and 50th days, yet during the impregnation period (slurry application).

The higher temperatures observed in the initial period of composting can inhibit nitrifying microorganisms which are mesophilic and thermosensitive (Paillat et al. 2005; Fukumoto et al. 2011) as consequence, there will be an increase on $\mathrm{NH}_{3}-\mathrm{N}$ available that can be volatilized. Additionally, the impregnation operation itself favors $\mathrm{NH}_{3}$ volatilization and emission once it involves frequent fresh slurry additions and turning allied with the temperature rise. After the impregnation period, emission rate decreases as compost maturation is progressing (Szanto et al. 2007; Hassouna et al. 2008).

The cumulative emission of $\mathrm{NH}_{3}-\mathrm{N}$ was higher as ryegrass straw proportion on bulking agent composition was increased. The dynamic of $\mathrm{NH}_{3}$ emission to atmosphere is driven by many factors but it is strongly influenced by some specific characteristics of composting biomass, mainly: $\mathrm{C} / \mathrm{N}$ ratio, $\mathrm{pH}$, porosity, organic carbon bioavailable, etc. (Meng et al. 2016).

Concerning the influence of $\mathrm{C} / \mathrm{N}$ ratio, there is consensus that the emission of $\mathrm{NH}_{3}$ is favored by low values of $\mathrm{C} / \mathrm{N}$ (De Guardia et al. 2010a; Matsumura et al. 2010), which is in agreement with the results found in this work once the piles with straw have lowest $\mathrm{C} / \mathrm{N}$ values (Table 3).

Also, the piles that contain higher straw content tend to be less compact due to its lower bulk density compared to wood shavings, this either can contribute to elevate the $\mathrm{NH}_{3}$ losses. Some papers have reported expressive reductions on $\mathrm{NH}_{3}$ emissions due to the reduction on inner free air spaces in the piles (Chadwick 2005; El Kader et al. 2007; Petersen and Sommer 2011).

The total accumulated losses of $\mathrm{NH}_{3}-\mathrm{N}$ per kilogram of $\mathrm{TN}$ (total nitrogen content of the biomass in the beginning of each treatment) were estimated after 85 days for the four treatments: $(W)=181.8 \mathrm{~g} \mathrm{NH}_{3}-\mathrm{N} \mathrm{kg}^{-1} \mathrm{TN}$ or $18.2 \% \mathrm{TN}$; $(W / S-50 / 50)=199.1 \mathrm{~g} \mathrm{NH}_{3}-\mathrm{N} \mathrm{kg}^{-1} \mathrm{TN}$ or $19.9 \% \mathrm{TN}$; $(W / S-30 / 70)=264.5 \mathrm{~g} \mathrm{NH}_{3}-\mathrm{N} \mathrm{kg}^{-1} \mathrm{TN}$ or $26.5 \% \mathrm{TN}$ and $(S)=279.6 \mathrm{~g} \mathrm{NH}_{3}-\mathrm{N} \mathrm{kg}^{-1} \mathrm{TN}$ or $28.0 \% \mathrm{TN}$.

The losses of $\mathrm{NH}_{3}-\mathrm{N}$ during swine slurries composting found in the literature have a wide range due to the high heterogeneity of raw materials and the differences on the managements. On spite of this, the values found in the present work do not differ greatly with recent international papers. According to Bernal et al. (2009) review, the swine slurry composting with corn stalk straw results in emissions that varied from 1.6 to $31.9 \% \mathrm{TN}$ (with turning) and from 4.3 to $32.4 \% \mathrm{TN}$ (without turning) whether for the mixture of swine slurries with wood residues (sawdust + shredded wood pallets) the emission was approximately $23.2 \% \mathrm{TN}$.

At the end of experiment, composts resulting from the four treatments evaluated had the average characteristics described in Table 5.

Although the highest losses of $\mathrm{NH}_{3}$ was observed in the piles that has higher straw content, the resulting composts
Table 5 Physico-chemical analysis of resulting composts after 100 days given in dry basis

\begin{tabular}{lcclllll}
\hline Bulking Agent & $\mathrm{K}\left(\mathrm{g} \mathrm{kg}^{-1}\right)$ & $\mathrm{P}\left(\mathrm{g} \mathrm{kg}^{-1}\right)$ & $\mathrm{TN}(\%)$ & $\mathrm{OC}(\%)$ & $\mathrm{C} / \mathrm{N}$ & $\mathrm{pH}$ & Moisture $(\%)^{\mathrm{a}}$ \\
\hline$W$ & $6.83 \pm 0.34$ & $14.5 \pm 0.7$ & $1.68 \pm 0.08$ & $35.0 \pm 1.8$ & 20.8 & 6.8 & 59.7 \\
$W / S-50 / 50$ & $10.3 \pm 0.52$ & $15.6 \pm 0.7$ & $2.20 \pm 0.10$ & $34.8 \pm 1.7$ & 15.8 & 6.8 & 63.3 \\
$W / S-30 / 70$ & $15.1 \pm 0.76$ & $16.2 \pm 0.8$ & $2.78 \pm 0.14$ & $28.0 \pm 1.4$ & 10.1 & 7.2 & 73.9 \\
$S$ & $27.7 \pm 1.40$ & $21.8 \pm 1.1$ & $2.65 \pm 0.13$ & $19.3 \pm 1.3$ & 7.3 & 7.3 & 73.4 \\
\hline
\end{tabular}

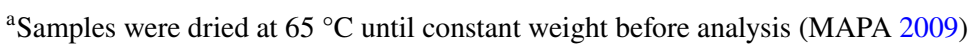


of this bulking agent presented more nutrient concentration. Overall, as higher was the proportion of straw in bulking agent composition higher was the NPK content in resulting products, except for $(W / S-30 / 70)$ which had higher $\mathrm{N}$ concentration than $(S)$. Despite this, increases in $\mathrm{NH}_{3}$ emission is always undesired because this gas is involved in acid deposition and eutrophication of aquatic habitats (Fukumoto et al. 2011). In addition to environmental issues, $\mathrm{NH}_{3}$ losses are undesirable also because $\mathrm{N}$ is a plant nutrient and its loss results in amendments with lower fertilizer potential, therefore, supplementary technologies aimed at mitigating this emission are required to enable any modification in co-composting operations.

The lack of correlation among $\mathrm{NH}_{3}-\mathrm{N}$ emission and TN content on final compost was previously reported by Lee, Rahman, and Ra (2009), according to whom this can be attributed to the differences in the decomposition rates of organic matter as composting progresses. This explanation seems to be plausible because the higher temperature peaks (observed mainly in the initial stage of composting), and the quick collapse of straw structures (compaction of piles) suggest that straw presented higher biodegradation rate compared to wood shaves.

The minimum requirements established by Brazilian Law (MAPA 2009) for organic fertilizer (compost from animal waste) are as follow: maximum moisture $50 \%$, $\mathrm{TN}>0.5 \%$ (dry basis), $\mathrm{pH} \geq 6.0, \mathrm{OC} \geq 15 \%$, and $\mathrm{C} / \mathrm{N}$ ratio $\leq 20$. Therefore, taking in account only the legal aspects concerning the resulting organic fertilizers; overall all the final composts achieve those requirements, except for the moisture content which was higher than the 50\% required. Nevertheless, besides moisture, there are other important parameters, not regulated by Brazilian current law, that have crucial importance to guarantee the compost quality and safety, such as electrical conductivity, heavy metals, pathogens, nutrients bioavailability, among others.

On the basis of the results of this work, it was identified the need for further studies that covers strategies to mitigate $\mathrm{NH}_{3}-\mathrm{N}$ losses in the beginning of slurries composting. Among the promisor technologies that can be highlighted: (a) physical barriers such as bin covers or the increase on biomass compacting (Chadwick et al. 2011); (b) additives to adjust $\mathrm{C} / \mathrm{N}$ ratio by supplying bioavailable carbon to the system (Matsumura et al. 2010), to immobilize the excess of $\mathrm{NH}_{3}-\mathrm{N}$ by precipitation (Fukumoto et al. 2011), adsorption (Villaseñor et al. 2011); (c) pH adjust, etc.

The manipulation of bulking agent composition may constitute in a useful tool to control the composting process, supplying the environmental conditions that favor the maximum microbiological activities and ensure the highest level of nutritional quality and sanity status of resulting final products.

\section{Conclusions}

Ryegrass straw can total or partially substitute wood shavings as bulking agent on swine slurry co-composting. The main advantage of wood shavings is its higher absorption and insulation capacity, whilst straw has higher biodegradability and results in richer composts. Although $\mathrm{NH}_{3}$ emission increased proportionally to straw content in bulking agent, its higher losses of mass compared to wood shavings resulted in end-composts with higher nutrients content. The substrates blends looks very promising, however, further studies approaching management adjusts are required to prevent increasing the emission of $\mathrm{NH}_{3}-\mathrm{N}$ and leaching.

Acknowledgements Authors would like to thank Santa Catarina Research Foundation-FAPESC (Project Number 08878/2007-1) for the financial support and Coordination for the Improvement of Higher Education Personnel-CAPES for the Master degree scholarship.

\section{Compliance with ethical standards}

Conflict of interest The authors declare that they have no conflict of interest.

Open Access This article is distributed under the terms of the Creative Commons Attribution 4.0 International License (http://creativeco mmons.org/licenses/by/4.0/), which permits unrestricted use, distribution, and reproduction in any medium, provided you give appropriate credit to the original author(s) and the source, provide a link to the Creative Commons license, and indicate if changes were made.

\section{References}

Adhikari BK, Barrington S, Martinez J, King S (2009) Effectiveness of three bulking agents for food waste composting. Waste Manag 29:197-203. https://doi.org/10.1016/j.wasman.2008.04.001

Angelo C (2012) Brazil's fund for low-carbon agriculture lies fallow. Nature News and Comment. In: Nature.com. http://www.natur e.com/news/brazil-s-fund-for-low-carbon-agriculture-lies-fallo w-1.11111. Accessed 6 Jun 2016

AOAC (1998) Official methods of analysis of AOAC international. Assoc Off Anal Chem Int CD-ROM. https://doi. org/10.3109/15563657608988149

APHA, AWWA, WEF (1999) Standard methods for the examination of water and wastewater, 20th edn. APHA/AWWA/WEF, Baltimore

Bernal MP, Alburquerque JA, Moral R (2009) Composting of animal manures and chemical criteria for compost maturity assessment. A review. Bioresour Technol. https://doi.org/10.1016/j.biort ech.2008.11.027

Cardoso AS, Berndt A, Leytem A, Alves BJR, Carvalho INO, Soares LHB, Urquiaga S, Boddey RM (2016) Impact of the intensification of beef production in Brazil on greenhouse gas emissions and land use. AGSY 143:86-96. https://doi.org/10.1016/j. agsy.2015.12.007

Chadwick DR (2005) Emissions of ammonia, nitrous oxide and methane from cattle manure heaps: effect of compaction and covering. Atmos Environ. https://doi.org/10.1016/j.atmosenv.2004.10.012 
Chadwick D, Sommer S, Thorman R, Fangueiro D, Cardenas L, Amon B, Misselbrook T (2011) Manure management: implications for greenhouse gas emissions. Anim Feed Sci Technol 166-167:514531. https://doi.org/10.1016/j.anifeedsci.2011.04.036

Cherubini E, Zanghelini GM, Alvarenga RAF, Franco D, Soares SR (2015) Life cycle assessment of swine production in Brazil: a comparison of four manure management systems. J Clean Prod 87:68-77. https://doi.org/10.1016/j.jclepro.2014.10.035

Cook KL, Ritchey EL, Loughrin JH, Haley M, Sistani K, Bolster C (2015) Effect of turning frequency and season on composting materials from swine high-rise facilities. Waste Manag 39:8695. https://doi.org/10.1016/j.wasman.2015.02.019

De Guardia A, Petiot C, Rogeau D, Druilhe C (2008) Influence of aeration rate on nitrogen dynamics during composting. Waste Manag 28:575-587. https://doi.org/10.1016/j.wasma n.2007.02.007

De Guardia A, Mallard P, Teglia C, Marin A, Le Pape C, Launay M, Benoist JC, Petiot C (2010a) Comparison of five organic wastes regarding their behaviour during composting: Part 2, nitrogen dynamic. Waste Manag. https://doi.org/10.1016/j.wasma n.2009.10.018

De Guardia A, Mallard P, Teglia C, Marin A, Le Pape C, Launay M, Benoist JC, Petiot C (2010b) Comparison of five organic wastes regarding their behaviour during composting: Part 1, biodegradability, stabilization kinetics and temperature rise. Waste Manag 30:402-414. https://doi.org/10.1016/j.wasman.2009.10.019

Dennehy C, Lawlor PG, Jiang Y, Gardiner GE, Xie S, Nghiem D, Zhan $X$ (2017) Greenhouse gas emissions from different pig manure management techniques: a critical analysis. Front Environ Sci Eng 11:1-16. https://doi.org/10.1007/s11783-017-0942-6

El Kader NA, Robin P, Paillat J-M, Leterme P (2007) Turning, compacting and the addition of water as factors affecting gaseous emissions in farm manure composting. Bioresour Technol 98:2619-2628. https://doi.org/10.1016/j.biortech.2006.07.035

FAO_Food and Agriculture Organization of the United Nations (2015) Food outlook-biannual report on global food markets, October 2014. Rome

Fukumoto Y, Suzuki K, Kuroda K, Waki M, Yasuda T (2011) Effects of struvite formation and nitratation promotion on nitrogenous emissions such as $\mathrm{NH}_{3}, \mathrm{~N}_{2} \mathrm{O}$ and $\mathrm{NO}$ during swine manure composting. Bioresour Technol 102:1468-1474. https://doi.org/10.1016/j. biortech.2010.09.089

Hassouna M, Espagnol S, Robin P, Paillat J-M, Levasseur P, Li Y (2008) Monitoring $\mathrm{NH}_{3}, \mathrm{~N}_{2} \mathrm{O}, \mathrm{CO}_{2}$ and $\mathrm{CH}_{4}$ emissions during pig solid manure storage and effect of turning. Compost Sci Util $16: 267-274$

Horwath WR, Elliott LF (1996) Ryegrass straw component decomposition during mesophilic and thermophilic incubations. Biol Fertil Soils. https://doi.org/10.1007/s003740050053

Lee Y, Oa SW (2013) Nutrient transport characteristics of livestock manure in a farmland. Int J Recycl Org Waste Agric 2:1-6. https ://doi.org/10.1186/2251-7715-2-1

Lee JE, Rahman MM, Ra CS (2009) Dose effects of $\mathrm{Mg}$ and $\mathrm{PO}_{4}$ sources on the composting of swine manure. J Hazard Mater 169:801-807. https://doi.org/10.1016/j.jhazmat.2009.04.026

Lockyer DR, Whitehead DC (1990) Volatilization of ammonia from cattle urine applied to grassland. Soil Biol Biochem 22:1137-1142

Macleod M, Gerber P, Mottet A, Tempio G, Falcucci A, Opio C, Vellinga T, Henderson B, Steinfeld H (2013) Greenhouse gas emissions from pig and chicken supply chains-a global life cycle assessment

Malinska K, Zabochnicka-Swiatek M, Dach J (2014) Effects of biochar amendment on ammonia emission during composting of sewage sludge. Ecol Eng 71:474-478. https://doi.org/10.1016/j.ecole ng.2014.07.012
MAPA-Ministério da Agricultura (2009) Pecuária e Abastecimento, Ministério do Desenvolvimento Agrário coordenação da CC da P da R. INSTRUÇÃO NORMATIVA N ${ }^{\circ} 25$. Brazil

Matsumura H, Sasaki M, Kato SI, Nakasaki K (2010) Unusual effects of triacylglycerol on the reduction of ammonia gas emission during thermophilic composting. Bioresour Technol. https://doi. org/10.1016/j.biortech.2009.11.006

Meng L, Li W, Zhang S, Wu C, Jiang W, Sha C (2016) Effect of different extra carbon sources on nitrogen loss control and the change of bacterial populations in sewage sludge composting. Ecol Eng 94:238-243. https://doi.org/10.1016/j.ecoleng.2016.05.013

Paillat JM, Robin P, Hassouna M, Leterme P (2005) Predicting ammonia and carbon dioxide emissions from carbon and nitrogen biodegradability during animal waste composting. Atmos Environ. https://doi.org/10.1016/j.atmosenv.2005.07.045

Petersen SO, Sommer SG (2011) Ammonia and nitrous oxide interactions: roles of manure organic matter management. Anim Feed Sci Technol 166-167:503-513. https://doi.org/10.1016/j.anife edsci.2011.04.077

Philippe F-X, Nicks B (2015) Review on greenhouse gas emissions from pig houses: production of carbon dioxide, methane and nitrous oxide by animals and manure. Agric Ecosyst Environ 199:10-25. https://doi.org/10.1016/j.agee.2014.08.015

Qasim W, Lee MH, Moon BE, Okyere FG, Khan F, Nafees M, Kim HT (2018) Composting of chicken manure with a mixture of sawdust and wood shavings under forced aeration in a closed reactor system. Int J Recycl Org Waste Agric 7:261-267. https://doi. org/10.1007/s40093-018-0212-z

Rawluk CDL, Grant CA, Racz GJ (2001) Ammonia volatilization from soils fertilized with urea and varying rates of urease inhibitor NBPT. Can J Soil Sci 81:239-246

Reinhard B (2006) Valorisation concepts for biodigestor effluent valorisation concepts for biodigestor effluent. HSW University of Applied Science-Applied Science Universitis Zurich

Ren L, Schuchardt F, Shen Y, Li G, Li C (2010) Impact of struvite crystallization on nitrogen losses during composting of pig manure and cornstalk. Waste Manag 30:885-892. https://doi. org/10.1016/j.wasman.2009.08.006

Ribeiro TMD, Monteiro ALG, Poli CHEC, Moraes A, Silva ALP, Barros CS (2009) Características da pastagem de azevém e produtividade de cordeiros em Ryegrass pasture characteristics and lamb productivity in grazing. Rev Bras Zootec 38:580-587

Rochette P, Chantigny MH, Angers DA, Bertrand N, Côté D (2001) Ammonia volatilization and soil nitrogen dynamics following fall application of pig slurry on canola crop residues Ammonia volatilization and soi1 nitrogen dynamics following fall application of pig slurry on canola trop residues. Can J Soil Sci 81:515-526. https://doi.org/10.4141/S00-044

Sardá LG, Higarashi MM, Muller S, Oliveira PA, Comin J (2010) Redução da emissão de $\mathrm{CO}_{2}, \mathrm{CH}_{4}$ e $\mathrm{H}_{2} \mathrm{~S}$ através da compostagem de dejetos suínos (Reduction emissions of $\mathrm{CO}_{2}, \mathrm{CH}_{4}$ and $\mathrm{H}_{2} \mathrm{~S}$ through composting of swine manure). Rev Bras Eng Agríc Ambient 14:1008-1013. https://doi.org/10.1590/S1415-43662 010000900014

Smith E, Gordon R, Bourque C, Campbell A (2007) Comparison of three simple field methods for ammonia volatilization from manure. Can J Soil Sci 7:469

Sommer SG, Møller HB (2000) Emission of greenhouse gases during composting of deep litter from pig production-effect of straw content. J Agric Sci 134:327-335. https://doi.org/10.1017/S0021 859699007625

Sommer SG, McGinn SM, Hao X, Larney FJ (2004) Techniques for measuring gas emissions from a composting stockpile of cattle manure. Atmos Environ 38:4643-4652. https://doi.org/10.1016/j. atmosenv.2004.05.014 
Sorathiya LM, Fulsoundar AB, Tyagi KK, Patel MD, Singh RR (2014) Eco-friendly and modern methods of livestock waste recycling for enhancing farm profitability. Int J Recycl Org Waste Agric. https ://doi.org/10.1007/s40093-014-0050-6

Szanto GL, Hamelers HVM, Rulkens WH, Veeken AHM (2007) $\mathrm{NH}_{3}$, $\mathrm{N}_{2} \mathrm{O}$ and $\mathrm{CH}_{4}$ emissions during passively aerated composting of straw-rich pig manure. Bioresour Technol 98:2659-2670. https:// doi.org/10.1016/j.biortech.2006.09.021

Villaseñor J, Rodríguez L, Fernández FJ (2011) Composting domestic sewage sludge with natural zeolites in a rotary drum reactor.
Bioresour Technol 102:1447-1454. https://doi.org/10.1016/j.biort ech.2010.09.085

Wang Q, Li R, Cai H, Awasthi MK, Zhang Z, Wang JJ, Ali A, Amanullah M (2016) Improving pig manure composting efficiency employing Ca-bentonite. Ecol Eng 87:157-161. https://doi. org/10.1016/j.ecoleng.2015.11.032

Publisher's Note Springer Nature remains neutral with regard to jurisdictional claims in published maps and institutional affiliations. 